\title{
Post-accretionary Stage in the Evolution of Ultramafic Magmatism in Accretionary Prisms: Rock Types and Diamond Potential (on Example of East Russia)
}

\author{
Voinova, I.P., and Prikhodko, V.S.
}

Institute for Tectonics and Geophı̣sics, Khabarovsk 680063. Russia

Nappe-folded structures of the Sikhote-Alin ridge (East Russia) are an accretionary system formed as a result of Paleozoic and Mesozoic subduction processes. Accretionary prisms were formed by nappe packets and plates. They are composed of Carboniferous, Permian, Triassic. Jurassic and Early Cretaceous volcanogenic-terrigenous-siliceous complexes within Middle Jurassic-Lower Cretaceous turbidite matrix. Ultramafics, gabbroids, tholeiitic and alkali basalts are associated with Late Triassic-Early Cretaceous siliceous and terrigenous rocks.

L'ltramafic volcanites are represented by meymechitic breccias making up pipe-like bodies, more rarely by mesmechitic lavas forming layered bodies and dikes. Meymechites are spacially associated with mafic volcanites (picrites and picrobasalts) making up siliceous-terrigenous complexes. Picrobasalts are of alkaline nature and are subdivided into sodic and potassic types. Mafic rocks were generated in oceanic intraplate environments. Ferro-titanium specialization and a similar style of minor elements distribution are common both for ultramafic and mafic rocks which testifies to their affinity. Meymechites similar to the meymechites from the Maimecha-Kotuisk province of the Siberian platform are associated with sodic picrobasalts, and meymechites smilar to meymechites from Japan. Sakhalin and the Koryak uplands - with potassic ones.

Petrogeochemical similarity with the pre-accretionary mafic rocks testifies to the meymechites" relationship with an accretionary process. Judging by the bodies' shapes (explosion pipes) and renoliths (basalts, siliceous rocks, sandstones and minerals of disintegrated mantle peridotites) meymechites formed during a post-accretionary stage in the prism evolution. Chemical composition of meymechites was dependent on the degree of the accretionary prism maturity expressed by its getting thicker in the process of evolution. A gradual alteration of the meymechites composition wards their platform analogues allow one to believe in the existence of kimberlites in the most mature accretionary prisms. 